\title{
The Memory of Feeling: Envy and Happiness
}

\author{
Jaco J. Hamman
}

Published online: 29 August 2013

(C) Springer Science+Business Media New York 2013

\begin{abstract}
This essay explores how happiness is maintained as a memory of the first relationship and when that memory is disturbed, envy can set in. Envy is the angry feeling that another person possesses and enjoys something desirable - the envious impulse being to take it away or to spoil it. The thought of Melanie Klein and her 1957 work, Envy and Gratitude, guides the inquiry. Happiness in one person can offend when another experiences the happiness as goodness of life that is being withheld from them. Since all persons carry the memory of happiness, seeing the happiness of others reminds us of something once owned or experienced, but now lost. Envy becomes a defense against the painful memory of happiness once known. The biblical figure King Saul is identified as someone who experienced envy in the face of a young David's happiness. Envy not only robs a person of happiness, it removes a sense of gratitude.
\end{abstract}

Keywords David $\cdot$ Envy $\cdot$ Gratitude $\cdot$ Happiness $\cdot$ Melanie Klein $\cdot$ Saul

\section{Introduction}

In 100 Years of Happiness, Carlin and Capps (2012) write that Saint Augustine was concerned with the question of happiness. He came to the conclusion that "we all had happiness once upon a time. In other words, happiness is somewhere in our memories" (p. xvii). What happens if the memory of happiness in a person is awakened and possibly disturbed? This is the foundational question that drives this essay. If we all have memories of happiness, as Augustine, Capps, Carlin, and many others argue, then memories of happiness may be stirred-or more pertinently, disturbed - especially by the happiness one witnesses in someone else.

Carlin and Capps address topics such as "The Desire of Happiness," "The Science of Happiness," "The Conquest of Happiness," "The Pursuit of Happiness," "Authentic Happiness," "Realistic Happiness," and "Evolving Happiness." These chapter titles have a positive, even a "happy" tone, as might be expected of a book on happiness, even though one chapter does address "Against Happiness." A chapter on happiness and its relationship with envy might be called "The Offense of Happiness." Following Klein, I define envy in this essay as "the angry feeling that another person possesses and enjoys something desirable - the envious impulse being to take it away or to spoil it" (1975, p. 181).

\section{J. J. Hamman ( $\triangle)$}

Vanderbilt Divinity School, 411 21st Avenue South, Nashville, TN 37240, USA

e-mail: jaco.hamman@vanderbilt.edu 
In this essay, I first look at the unrestricted happiness of the biblical figure David and those around him and the envy that it stirred in his king, Saul. Here, I believe, we find a primal narrative: Happiness in one awakens envy in another. Next, the contribution of Melanie Klein around envy and gratitude is discussed. Envy's origins are sought and its defenses identified. We return then to the narrative of Saul and David, reading it through the lens of Klein's concept of envy.

\section{A narrative of envy and happiness}

According to the narrative of 1 Samuel 18, David was a happy man. First, the king's son, Jonathan, "became one spirit with David, and he loved him as himself" (v. 1) (The Bible: New International Version, 1984). Capps and Carlin reference Jean Finot's The Science of Happiness (published in 1914), in which Finot identifies friendship and admiration as key elements to happiness. "In friendship," Carlin and Capps summarize Finot, "as in love, what is important is the joy we have derived from the feeling of friendship, for even if we have been betrayed, no one can deprive us of the emotions we have enjoyed" (2012, p. 32). Finot suggests that we might even speak of the delight of admiration and that those who maintain admiration are happier for it. The authors also reference Richard Layard's Happiness: Lessons from a New Science (published in 2005), in which Layard identified friendship amongst other variables such as family relationships, financial situations, and health as foundational to happiness (p. 94).

It was, however, not only friendship and admiration that brought happiness to David. David also had significant victories on the battlefield. The narrator tells that King Saul sent David into battle on his behalf and that David was very successful, so much so that he was promoted to a high rank in the army, which pleased all the soldiers. The women of neighboring towns came out singing and dancing, officially to pay homage to Saul but in reality to join in the happiness and elation around David. Maybe they anticipated that Saul's kingship was coming to an end and that they were celebrating the next king (vv. 6-8):

The women came out from all the towns of Israel to meet King Saul with singing and dancing, with joyful songs and with timbrels and lyres. As they danced, they sang: "Saul has slain his thousands, and David his tens of thousands." Saul was very angry; this refrain displeased him greatly. (emphasis added)

Biblical scholars are slow to identify the envy in 1 Samuel 18, even though envy is all too common in Scripture. In Genesis 4, Cain was envious of Abel (see Kim 2001), and Mark (15:10) suggests that Jesus was killed out of envy (see Hagedorn and Neyrey 1998), to name just two important passages. Reflecting on verses 6-9, Old Testament scholar Walter Brueggemann writes:

The sudden, unexpected eruption of hostility on Saul's part in this episode comes as an abrupt shock to us. The two men return victorious from the battle with the Philistines (v 6). The return is a triumph for both the successful king and the young warrior. The victory over the Philistines has been an enormous one (17:52-53). There is enough triumph for the celebration of both men. There is no reason to anticipate tension or competition between them upon their return. (p. 228)

Brueggemann, it seems, is surprised by Saul's blind rage and destructiveness: "Whatever the intent of the women's song, which the narrator presents as innocent, the parallelism triggers Saul's rage against David, rage which from now on will be a key factor in their relationship (v. 8)" (Brueggemann 1993, p. 229). The narrator tells how Saul, having observed 
the happiness and admiration of David, became angry and "displeased" by the singing and dancing around him. From that moment, Saul "kept a close eye on David" (v. 9). Moreover, an "evil spirit" (which according to the narrator came from God) came over Saul, and while David was playing the lyre, Saul grabbed a spear and hurled it at David, saying to himself: "I'll pin David to the wall" (v. 10). David, however, eluded Saul twice. The narrator states that Saul remained afraid of David because the Lord's spirit left Saul and David remained successful in battle. Even though David married Saul's daughter Michal and paid a bride's price of 200 foreskins of Philistine soldiers, Saul's relationship with his son-in-law David never changed, with the narrative stating that Saul remained afraid of David all his life and saw David as his enemy.

\section{No happiness without envy}

In 100 Years of Happiness, envy is a thread one can follow throughout the book as numerous authors on happiness are introduced by Carlin and Capps. Two authors address envy directly, Bertrand Russell and David Myers. Bertrand Russell, the British philosopher, mathematician, and social critic, has a chapter on envy in his The Conquest of Happiness (published in 1930). Carlin and Capps state that for Russell, envy, next to worry, "is one of the most potent causes of unhappiness" (2012, p. 46). For Russell, envy is a powerful passion that one sees mostly in children, less often in adults, and that can be countered through admiration. Carlin and Capps write:

Russell believes that happiness is the cure for envy, but the problem is that envy is itself a terrible obstacle to happiness, and, moreover, envy is deeply rooted in misfortunes in childhood and is therefore difficult to eradicate because it has become part of oneself. (p. 46)

For Russell, acknowledging one's envious feelings is a step away from envy (and a step towards happiness). So too is avoiding comparisons. If Saul could have stayed in the moment of happiness surrounding the victories of David, Russell would say, he would have been less envious of David. "Envy, then, is a vice, partly moral and partly intellectual, which consists in not seeing things in themselves but only in their relationships" (Carlin and Capps 2012, p. 47). If Saul had had the mental discipline to reflect on himself being the king and divert his focus away from David, he might have felt less envy. Russell's argument on envy, linked as it is with competition, boredom, excitement, fatigue, a sense of sin, persecution mania, and fear of public opinion, is persuasive. Whereas Russell identifies envy as amongst the causes of unhappiness and an obstacle to happiness, this essay argues that happiness awakens envy and the two experiences are inseparably linked.

Another researcher covered by Carlin and Capps who addresses envy is social psychologist David Myers, whose book The Pursuit of Happiness was published in 1992. Myers argues for a general "well-being," of which happiness is a constitutional part. For Myers, happiness is "an ongoing perception that this moment of one's life, or even one's life as a whole, is fulfilling, meaningful, and pleasant" (Carlin and Capps 2012, p. 57). Happy people think that their lives are satisfying. Myers notes that happiness is relative to prior experience and to what others, especially those close to us, have. Here, Myers joins Russell, who advised against comparing oneself with others because, as Russell indicated, this kind of comparison awakens envy (p. 60). One difference between Myers and Russell, however, is that when one compares "downward," as Myers advocates, as in the situation where an older woman with breast cancer thinks of a younger woman with breast cancer and thinks that the younger 
woman is in a worse situation, one might actually improve one's well-being. For Myers, people tend to look on the brighter side of life. One way they can avoid comparison and envy is "to avoid thinking of past experiences of happiness" (p. 61). Research quoted by Myers and identified by Carlin and Capps even shows that thinking of a difficult time in the past can lift one higher than recalling a past positive event. What happens, however, if one unconsciously is reminded of happiness once experienced? What if merely refusing to remember or even to remember "downward" is not a conscious choice? Most persons may lack the consciousness Myers identifies. In the narrative of David and Saul, for example, the consciousness belonged to the narrator.

It is apparent from the books addressed in 100 Years of Happiness that envy and happiness are intimately linked. Whether happiness is robbed by envy as its intimate enemy or whether happiness causes envy might be two sides of the same coin. Envy, however, is a powerful emotion in relation to happiness that is worth exploring more. Melanie Klein addressed envy most notably in her book, Envy and Gratitude, which was published in 1957, but many of her papers also addressed envy: "The Psychological Principles of Early Analysis" (1926); "Early Stages of the Oedipus Conflict" (1928); "The Importance of Symbol Formation in the Development of the Ego" (1930); and "The Early Development of Conscience in the Child" (1933), to name just a few of her earlier papers on envy (all articles can be found in Klein 1984). Because she explored the earliest roots of envy in our psyches, Klein's insights might prove fruitful in a discussion of happiness and memories of happiness.

\section{Melanie Klein: a brief introduction}

Described as "the psychoanalyst of the passions" (Alford 1989, p. 23), Klein remains a controversial figure within psychoanalytic studies. Possibly for this reason, her contributions are relatively unexplored, especially in religious scholarship. An ATLA Religion subject search spanning the last 30 years indicated 23 entries on Klein compared to 631 entries on Sigmund Freud, 532 entries on Carl Gustav Jung, 130 entries on Erik Erikson, and 61 entries for D. W. Winnicott.

Melanie Reizes Klein (30 March 1882-22 September 1960) was a Jewish, Austrian-born psychoanalyst who practiced in London. The youngest of four children, she was influenced by her father, Moriz Klein, a medical doctor who often took patients, especially those with cholera, who could not find physicians who would treat them. Moriz was a rebel, going against his Orthodox Jewish family's wish that he would become a rabbi and later divorcing his first wife by arranged marriage (Sayers 1991, p. 205). Later in his life, he became a dentist. Likewise, Melanie Klein ventured into psychoanalytic terrain other psychoanalysts sidestepped, and her emphasis on the mother can lead her to be seen as a rebel. Klein's mother, Libussa Deutch - who became a business owner after her husband Moriz became senile - sold plants and reptiles, which meant that Melanie was raised by a wet-nurse (Kristeva 2001, p. 17). Libussa was dutiful rather than loving and had a distant relationship with her husband. Maybe in reaction to her absent father and distant mother, Melanie had close relationships with her siblings. Emilie was 6, Emmanuel 5, and Sidonie 4 when Melanie was born on March 30, 1882. Sidonie, who died early at age eight, generated a life-long feeling of gratitude in Melanie due to Sidonie's kindness when Melanie was teased by her siblings Emilie and Emmanuel. Melanie also had a close relationship with her brother Emmanuel, describing him as "my confidant, my friend, my teacher" (Segal, p. 4). Emmanuel, who had cardiac concerns after rheumatic fever at age 12, was envious of Melanie's beauty and health (Sayers, p. 207). While sharing with Klein about his affairs, he wondered aloud whether 
Arthur, Melanie's fiancé, was faithful to her. Klein was more distant from Emilie and her parents.

In 1903, at age 19, Melanie married Arthur Klein, a chemical engineer. When she married, Emmanuel became physically sick. Klein later shared that she knew the marriage was a mistake, but with her father ill and her family under pressure, she could not admit this to Arthur, her mother, or Emmanuel, who was travelling for health reasons. During her years of marriage she was tense, depressed, and unhappy. Arthur started having affairs soon after their marriage, and Klein struggled with "issues of sexuality, infidelity, love, friendship, abandonment, and death" (Segal 2004, p. 5). Still, the Klein couple had three children: Melitta (born 1904), Hans (born 1907), and Erich (born 1914). After a period of severe depression that sent Klein to a sanatorium in Switzerland for a few months, the family settled in Budapest in 1914 with the help of Emmanuel. There, Melanie entered analysis with Sándor Ferenzi, who advocated child analysis. The work and exploration of the unconscious became a spiritual home for Klein as she began making observations of her youngest son, Erich. She tried to raise Erich free from any restrictions, prohibitions, or distortions about sexuality and God (Segal 2004, p. 7). Her first psychoanalytic paper, based on her work with Erich, and encouraged by Ferenzi, was "The Development of a Child," which she delivered in 1919 to the Budapest Psychoanalytic Society. The paper described the sense of omnipotence a child feels and how it diminishes as reality sets in, how a child portrays repressed sexual curiosity, and how real a child's mental representations are. She called the representations phantasies as she distinguished unconscious phantasy from conscious fantasy. Facing growing anti-Semitism in Budapest, the family moved to Berlin in 1921. Here, Klein entered psychoanalysis with Karl Abraham in 1924. The analysis ended when Abraham died the following year.

Klein, the first recognized psychoanalyst who was a mother and also one of the first to analyze young children, was invited by Ernest Jones to London in 1925 to give lectures on child analysis. As Segal states, the focus on children was highly contentious:

Fears about the dangers of probing too much in children's unconscious were already surfacing when in 1924 the first analyst to attempt the analysis of children, Hermine Hug-Hellmuth, was murdered by an 18-year-old nephew she had brought up and attempted to analyse. (2004, p. 10)

Klein, fueled by the successes she had with children, disagreed with Hug-Hellmuth and her psychoanalytic peers that one should not pry too deep into children's psyches and saw lots of promise in analyzing children 3-6 years of age. Two years after her London lectures - which she describes as some of the happiest times of her life-opposition in Berlin to Klein's thought was strong because she did not hold a medical degree and she analyzed children. In 1926 Klein immigrated to London, where she lived until her death in 1960. Her controversial nature stems not only from her analyzing children and placing more emphasis on the mother than the father, but also from the fact that "where others modified their technique in the face of the anxieties arising from the work, Klein refused to modify hers" (Segal 2004, p. 1). Yet, she remained a sympathetic listener who believed that what a client told her was more important than why. This sympathy helped her in interpreting envy for her analysands.

At first, Klein's work was in line with the British Psychoanalytical Society, but her 1932 book The Psycho-Analysis of Children led to tension, especially with Anna Freud, who believed that children couldn't be analyzed. Klein continued drafting papers challenging core Freudian assumptions while arguing that she was expanding upon Freud's theories. She identified the Oedipal crisis in the first year of life, for example, and not in the third year as 
Freud envisioned. Klein also reinterpreted the meaning of the Oedipal crisis, by which she meant not a sexual interest in the mother, but rather a pregenital desire to possess and control the richness of the mother's body, a desire that incorporates oral phantasies. "[The Kleinian phantasy] consists of drives, sensations, and acts as well as words, and that is manifested just as much in the child at play as in an adult who describes his drives and sensations from the analytic couch using a discourse bereft of any motor manifestations" (Kristeva 2001, p. 13).

Klein also reinterpreted the superego to mean not the internalization of the father's authority, but the young child's innate sense of guilt at her own greed and aggression toward the mother (Alford 1989, p. 24). Klein's opposition further came from her daughter Melitta (Schmideberg), now an analyst herself, who in 1933 argued that Klein never paid attention to the role of the father and undervalued the role of external reality. Yet, Klein persisted. Psychoanalyst Gregory Hamilton, naming the importance of her contributions in regard to splitting, projection, and introjection, summarized Klein's controversial nature - and her contributions - as follows:

[Her] odd terminology, her insistence on concrete, anatomical metaphors, her concept of an inborn death instinct, her recommendation of deep interpretation early in therapy, her ideas about innate knowledge of sexual intercourse, her overemphasis on constitutional as opposed to environmentally determined development, and her idea that psychic development is condensed into the first months of postnatal life have interfered with both the understanding and the acceptance of her ideas. (1992, pp. 6-7)

A brief description spanning all of Klein's work is beyond this essay. Suffice it to say that Klein was surrounded by controversy and created a very different psychoanalytic theory in which the major moments of a child's life are pre-Oedipal. Despite departing from Freud on key psychoanalytic tenets, Klein held on to others, such as the death instinct. Klein described the death instinct differently from Freud, however. Whereas Freud saw the death instinct as emanating from bodily sensations such as the libido and aggression, which are objectless psychic energies, Klein saw the body as a means of expressing drives and libido and aggression as contained within the body. The libido always has an object in mind as a pattern of feelings in a relationship with others, whether real or imagined. "The body," Alford writes about Klein, "rather than being the instigator of the drives, is the universal medium through which they are expressed" (1989, p. 26).

Compared to Freud, Klein was much more interested in the object relationship than in the two objects who were in a relationship. Drives, for Klein, are relationships. Furthermore, the central human conflict is between love and hate. It is not the ego or the superego that controls aggression - as a natural response to frustration - but love. Through mechanisms such as projection, introjection, and projective identification (if I am mean to you, you'll be mean to me), the object relationship is built. Freud and Klein also overlapped on the splitting of the ego as a defense and on repression as a cause of anxiety, but they understood the repression differently. For Freud, anxiety stemmed from instinctual demands, whereas for Klein anxiety originated in the disintegrative effects of rage.

Another distinction between Klein and Freud is that Klein abandoned stages of development for "positions" birthed in unconscious phantasies. Phantasies, according to Klein, are a complex combination of impulses, defenses against them, and object relationships. The paranoid-schizoid position describes the earliest organization of an infant's defenses (which remains into adulthood) and takes the form of phantasies of persecution. A person, whether an infant or an adult, defends against this fear by idealization and by splitting the ego, a schizoid phenomenon, into bad objects and good objects (Kristeva 2001, p. 66). The ego-fearing death since the moment of birth - and the id are opposed and fuel repression. What the infant 
represses are fears of annihilation and disintegration as it creates the good breast and the bad breast, independent of parental care and love. If the anxiety related to the paranoid-schizoid position is not too great, the infant naturally enters into the depressive position.

Whereas a child in the paranoid-schizoid position fears destruction by others, the child in the depressive position fears her own destruction of others. This position refers to the 3month-old infant recognizing that the mother he hates is also the mother he loves (Klein 1975, p. 73). The integration of this awareness, that the loved object is also the hated object, is for Klein a life-long process. In the depressive position, the child has fears and anxieties tied to having destroyed a loved one in phantasy, and these fears become the foundation of a moral self as the child seeks restoration for the damage done. This foundation is stronger if the infant can establish a solid relationship with her loved objects. Thus, in the depressive position, the child, through feelings of love and gratitude, seeks reparation for the damage done to the loved objects in phantasy. Klein believed that the loss of a loved one in later life reactivates the depressive position.

\section{Melanie Klein on envy}

Important for this essay, however, are Klein's contributions on envy. When she first presented her thinking on envy in London, D. W. Winnicott famously and despairingly uttered (with his head in his hands): "Oh no, she can't do this!" (Likierman 2001, p. 172). At the age of 70 (in 1952), having faced many losses, including the death of her son Hans, estrangement from her daughter Melitta and close friend Paula Heimann, and with no recognition by Anna Freud, Klein focused on Envy and Gratitude. Depressed by these losses and concerned about nuclear war, she started working on her book, which was first published in 1957. The book drew on a paper on gratitude and envy she delivered in 1955 in Geneva. Klein introduces her book with this opening sentence: "I have for many years been interested in earliest sources of two attitudes that have always been familiar-envy and gratitude" (Klein 1975, p. 176). She continues: "I arrived at the conclusion that envy is a most potent factor in undermining feelings of love and gratitude at their root, since it affects the earliest relation of all, that to the mother." These two sentences set the tone for a book exploring the emotional lives we live. Klein (1975, p. 183) was the first psychoanalyst who made envy a key psychoanalytic construct:

My work has taught me that the first object to be envied is the breast, for the infant feels that it possesses everything he desires and that it has an unlimited flow of milk and love which the breast keeps for its own gratification. This feeling adds to his sense of grievance and hate and the result is a disturbed relation to the mother. If envy is excessive, this, in my view, indicates that paranoid and schizoid features are abnormally strong and that such an infant can be regarded as ill.

For Klein, envy is "an oral-sadistic and anal-sadistic expression of destructive impulses, operative from the beginning of life, and it has a continual basis" (1975, p. 176). She acknowledged that Karl Abraham's work on envy as an oral trait informed her thinking and saw herself as furthering his contribution, but she differentiated her theory from Abraham's by recognizing envy and destruction early in infancy and by addressing gratitude. In the book she describes how a small child attacks the breast that feeds her not only out of frustration, but also out of envy after the experience of a good feed or in the presence of good mothering. That goodness can be attacked was a radical interpretation. 
Closely identifying with Freud concerning the accessibility in adulthood of the unconscious life of childhood, she offers a lengthy quote from Freud:

What we are in search of is a picture of the patient's forgotten years that shall be alike trustworthy and in all essential respects complete. .. . [The psychoanalyst's] work of construction, or if it is preferred, of reconstruction, resembles to a great extent an archeologist's excavation of some dwelling-place that has been destroyed and buried or of some ancient edifice. The two processes are in fact identical, except that the analyst works under better conditions and has more material at his command to assist him. (Klein 1975, pp. 177-178)

In this quote from his 1937 essay "Constructions in Analysis," Freud continues to reflect on "fragments of memories" that show themselves in behavior and in free association, memories that the psychoanalyst can "reconstruct" to uncover deeper meaning; what seems forgotten is preserved and present somewhere and somehow. Klein uses Freud to validate her look at the earliest relationship infants have, but also to state that an adult cannot be understood without taking this earliest relationship into consideration. The relationship, of course, is "the infant's first object relation - the relation to the mother's breast and to the mother" (1975, p. 178). It is this object that is introjected by the child, which lays the foundation for healthy development. Here, the external environment plays an important role, and "a disturbance in the adaptation to the external world," especially when the infant is not cared for or adequately fed, impacts that process of introjection in significant ways. In such instances, an infant's ability to experience new gratifications is impaired.

When the infant is properly cared for, however, and "under the dominance of oral impulses," Klein writes, "the breast is instinctively felt to be the source of nourishment and therefore, in a deeper sense, of life itself" (1975, p. 178). The mental and physical presence of the breast restores a sense that things are well for the infant and fosters a sense of personal security. "The good breast is taken in and becomes part of the ego," Klein continues, "and the infant who was first inside the mother now has the mother inside himself" (p. 179). The longing for the good breast remains with us even into adulthood in the form of idealization, as we have internalized the good and the bad breast.

Since even the happiest feeding experiences cannot replace the unity that was in the womb, frustration in the infant is inevitable, fueling the idealization mentioned. This frustration also emanates from instinctual tensions and fears of being annihilated as the infant experiences tension between love and hate or between life and death instincts. Positively introjected, the breast becomes "the prototype of maternal goodness, inexhaustible patience and generosity, as well as creativeness" and the foundation of "hope, trust, and belief in goodness" (Klein 1975, p. 180). "Hope and trust in the existence of goodness, as can be observed in everyday life, helps people through great adversity, and effectively counteracts persecution," Klein concludes (p. 194). The hope stems from the growing unconscious knowledge that the internal and external object is not as bad as it was felt to be and that the destruction that occurred in the past was not severe and that future destruction will be less. The internal object gains "a restraining and selfpreservative attitude" (p. 196), and a sense of serenity sets in (p. 203). In the absence of hope and trust, however, envy sets in because the infant cannot build up a good object.

Segal (2004) summarizes these processes as follows:

A bad feeding experience may give rise to a sense that the breast has unlimited food and love which it is keeping for itself; a good experience can for some babies (and adults) be intolerable because it heightens awareness of the baby's own lack. The baby 
attacks the breast felt to be good, giving and creative: in later life this appears as the denigration of mothers; as mockery of people felt to have more than the self; as an inability to keep in mind the goodness of something seen as not belonging to the self. (p. 21)

One can argue that the breast being made good or bad through the psyche of the infant releases mothers from responsibility for being the cause of envy. However, by focusing on the breast and envy, Klein brought mothers into the conversation. Kristeva's question (2001, p. 114) of whether Klein created a cult of the mother or whether she committed matricide, or whether the two are related, speaks to the tension that surrounds Klein. Klein certainly recognized poor mothering, which enhances envy. Towards the end of Klein's life, she believed that people were born with different capacities for envy. When envy sets in, the enjoyment of life is under attack.

In discussing envy, Klein distinguished it from jealousy and greed:

Envy is the angry feeling that another person possesses and enjoys something desirable - the envious impulse being to take it away or to spoil it. Moreover, envy implies the subject's relation to one person only and goes back to the earliest exclusive relation with the mother. Jealousy is based on envy, but involves a relation between at least two people; it is mainly concerned with love that the subject feels is his due and has been taken away, or is in danger of being taken away from him by his rival. . . . Greed is an impetuous, an insatiable craving, exceeding what the subject needs and what the object is able and willing to give. . . Greed is mainly bound up with introjection and envy with projection. (1975, p. 181)

Envy describes "a relationship between an infant, the envied person, and the envied characteristic or possession" (Segal 2004, p. 56). Kristeva describes Klein's envy as more "archaic" than jealousy (2001, p. 91).

Jealousy, on the other hand, "is the relationship between the infant and two other people, one of whom the infant loves and the other of whom seems to the infant to be receiving the love which the infant wants and who becomes the object of hatred, anger and rivalry" (Segal 2004, p. 56). The jealousy is based "on suspicion of and rivalry with the father, who is accused of having taken away the mother's breast and the mother" (Klein 1975, p. 196). Jealousy excludes another from the source of what is experienced as the good: "I would interpret 'the good' basically as the good breast, the mother, a loved person, whom somebody else has taken away," Klein writes (1975, p. 182). She continues: "Jealousy fears to lose what it has, envy is pained at seeing another have that which it wants for itself."

Greed and envy are related, Klein argues, for the envious person is an insatiable person, never satisfied, for the envy stems from within and therefore always finds an object to focus upon. Envy is inherently singular as it focuses on a single person, actively seeking to control, possess, and destroy another person (Alford 1989, p. 4). If the person with envy cannot have what another has, then no one is allowed to have the good. Greed functions as a defense against the loss of the good breast. Of envy, greed, and jealousy, envy is the most damaging.

"Envy is extremely damaging primarily because it empties the world of goodness," Alford warns (1989, p. 37). When envy has set in, one's capacity to notice the good object diminishes and other good objects are spoiled and devalued. One is left with persecutors one is set to destroy, grabbing the first spears in sight. Also, one's future of hope is closed. Psychoanalytic historians Jay Greenberg and Stephen Mitchell succinctly state: "Envy destroys the possibility of hope" (1983, p. 129). Envy disallows the possibility of restoration, or the return to a state of wholeness. As envy increases and the good internal object diminishes, the ego feels impoverished and envy increases even further. 
As hope is destroyed, persecutory anxieties (other objects are out to get me and are an inherent threat) and greed increases, fueling envy in a vicious cycle (Klein 1975, p. 183). This leads to sadistic attacks, which Klein recognized in the behavior of the children she analyzed. As stated, both the good and the bad breast can initiate this cycle. Klein saw this dynamic in her patients. She describes how an analyst gave an interpretation that benefited her patient and brought relief and a changed mood of hope and trust. With some patients, she writes, this helpful interpretation becomes the object of destructive criticism:

It is no longer felt as something good that he has received and has experienced as an enrichment. His criticism may attach itself to early points; the interpretation should have been given earlier; it was too long, and has disturbed the patient's associations; or it was too short, and this implies that he has not been sufficiently understood. The envious patient grudges the analyst the success of his work. (1975, p. 184)

The envious person rejects by devaluing the other they meet or the interpretation they receive. Or, the envious person becomes confused, thereby avoiding criticism. The paranoid and schizoid uncertainty the envious person experiences, Klein believed, reflects uncertainty experienced in the disturbed first object relationship the person had. In the transference relationship, then, the earliest stage where the good object could not be received is repeated. Analytic work helps the envious person to restore and "reconstruct the patient's feelings as a baby towards the mother's breast" $(1975$, p. 185). Where once the milk came too quickly or too slowly, or the breast was not present at all and the baby turned to sucking a thumb instead, similar dynamics can be identified in the transference relationship.

To repeat what has been said, when envy spoils the primal good object, impetus is added to the sadistic attacks on the breast, which now has lost all value. "Excessive envy increases the intensity of such attacks and the duration," Klein writes, "and thus makes it more difficult for the infant to regain the lost good object." (1975, p. 186).

With her theories about envy, gratitude, jealousy, and greed, Klein not only shifted beyond mental mechanisms (such as projection and introjection), but also described emotional currents that shape the course of mental life (Likierman 2001, p. 176). Of these forces, gratitude shapes in positive ways. Attacks on the breast that are not fueled by envy are shortlived, and the breast can be experienced as being also good. Gratitude is the expression that follows the experience of a gift received from the good breast.

\section{Klein on gratitude}

In her 1959 paper, "Our Adult World and Its Roots in Infancy," Klein wrote:

It is not for nothing that in saying grace before meals, Christians use the words, 'For what we are about to receive may the Lord make us truly thankful.' These words imply that one asks for the one quality - gratitude - which will make one happy and free from resentment and envy. I heard a little girl say that she loved her mother most of all, because what would she have done if her mother had not given birth to her and had not fed her? $(1975$, p. 254)

Klein found a connection between the capacity for enjoyment and gratitude, which makes a variety of pleasures and interests possible. She further explored this theme in Envy and Gratitude.

When envy is interpreted, Klein believed that a sense of goodness and value — gratitude — could set in. Interpretation can thus have dramatic results: "Where [envy] can be recognized and 
overcome, past good experiences can be remembered and love regained: this can then create a benevolent cycle in which many good feelings which previously had to be denied can now be tolerated" (Segal 2004, p. 75). These good feelings and general sense of well-being create what Klein called a sense of "enjoyment" and "gratitude" (1975, p. 187).

Gratitude, which Klein spoke of as an innate "capacity to love" $(1975$, p. 187), is essential in the building of a good relationship. She returned to a compassionate, positive appraisal of the human psyche. Klein believed gratitude is rooted in the emotions and attitudes that arise in early infancy, when the mother is the only object for the baby. This close bond between an infant and a primary caregiver is important, and "I believe," she writes, "up to a point . . . exists in most people" (1975, p. 188). A strong sense of envy, however, can disrupt the capacity to love and the sense of gratitude. "The infant can only experience complete enjoyment if the capacity for love is sufficiently developed; and it is enjoyment that forms the basis for gratitude," Klein continues (1975, p. 188). This enjoyment and the good feeding

[constitute] not only the basis for sexual gratification, but all later happiness, and make possible the feeling of unity with another person; such unity means being fully understood, which is essential for every happy love relation and friendship. At best, such an expression needs no words to express it, which demonstrates its derivation from the earliest closeness with the mother in the preverbal stage. $(1975$, p. 188)

We carry, according to Klein, a deep longing to be understood without words (Likierman 2001, p. 192). As is clear from the paragraph above, the source of happiness is preverbal, and its memory resides deep in the human psyche. When good relations occur, the capacity for love in the infant is strong and the infant can withstand destructive impulses and persecutory anxieties. In therapy, as in the creation of art and literature (see Alford 1989, on art and Sanchez-Pardo 2003 , on literature), reparation can occur as the capacity to love is strengthened. The attitude of the analyst contains (holds) the analysand, allowing for the former to be introjected by the latter as the good object, possibly even as the first good object. If a relationship of trust exists between analyst and analysand, words might not be needed to awaken this memory. Conversely, the memory of the first love object can be disturbed (and the analyst can become a bad object) and, being preverbal, the envy that follows is not easily made conscious.

Klein believed the "more often gratification at the breast is experienced and fully accepted, the more often enjoyment and gratitude, and accordingly the wish to return pleasure, are felt" (1975, p. 189). This deep-seated sense of gratitude cultivates a sense of generosity. "Inner wealth," Klein continues, "derives from having assimilated the good object so that the individual becomes able to share it with others" (1975, p. 189). With an introjection of a good breast, seeing a friendlier outer world is possible. Those who lack inner wealth may still be generous, but act out of feelings of guilt and afterwards are in need of excessive appreciation and gratitude as they fight off persecutory anxieties. "It is my hypothesis that one of the deepest sources of guilt is always linked to envy of the feeding breast, and with the feeling of having spoilt its goodness in envious attacks," Klein writes (1975, p. 195). It is no surprise, Klein concludes, that envy ranks high among the deadly sins: "I would even suggest that it is unconsciously felt to be the greatest sin of all, because it spoils and harms the good object which is the source of life" (1975, p. 189).

Following Kleinian psychodynamics, happiness is a form of "inner wealth." One can thus say that all happiness is either undisturbed happiness, which leads to a sense of gratification and enjoyment, or it is disturbed happiness, leading to envy. "A full gratification at the breast means that the infant feels he has received from his love object a unique gift which he wants to keep" (1975, p. 188). 


\section{Envy and its defenses}

After expounding the theoretical foundation of her essay, much of which has been summarized in the previous section, Klein provides some clinical examples followed by a section on the ways we defend against envy. These defenses against envy include attacking or spoiling the good object, but there are others too. The first defense mechanism she addresses is idealization. "Excessive idealization," Klein identified, "denotes that persecution is the main driving force" (1975, p. 193). "Strongly exalting the object and its gifts is an attempt to diminish envy," Klein writes (1975, p. 216). When a person idealizes an object, that object is rarely introjected to the extent that a loved object is introjected. Rather, the idealized object can awaken "a longing for the good object and for the capacity to love it" (1975, p. 216). Klein believed that envy is always part of idealization because the envy of the good object is extended to the idealized object. The envy tied to the idealized object is one reason why whatever is idealized can easily be attacked. "The former idealized person is often felt as a persecutor (which shows the origin of idealization as a counterpart to persecution) and into him is projected the subject's envious and critical attitude," Klein writes (1975, p. 193).

Linked to idealization is ambition as a defense. Of course, ambition speaks of rivalry and competition, dynamics Klein identified as tied to the Oedipal struggle and its penis envy, the latter of which, as stated, she saw as breast envy. "Failure to fulfill one's ambition is often aroused by the conflict between the urge to make reparation to the object injured by destructive envy and a renewed appearance of envy" (1975, p. 199).

Another defense against envy is confusion. "Confusion is not only a defense, but also expresses the uncertainty as to whether the analyst is still a good figure, or whether he and the help he is giving have become bad because of the patient's hostile criticism" (1975, p. 199). Normal splitting into good and bad objects has not occurred. "By becoming confused as to whether a substitute for the original is good or bad," Klein writes, "persecution as well as the guilt about spoiling and attacking the primary object by envy is to some extent counteracted" (1975, p. 216). The confusion, according to Klein, can be so severe that a person can develop schizophrenia (1975, p. 220).

Flight from the mother to other people, especially to persons one has idealized, is another defense. When one admires, Klein found, one has less hostile feelings to deal with. This is also an attempt for the loving breast to be preserved. Here, Klein felt that the father-figure can play an important role, allowing the child to turn towards someone else. Widening of object relations is to be expected, but if one flees due to envy, one takes that envy into the new relationships.

A further defense against envy is devaluation of the object (Klein 1975, p. 217). A devalued object need not be envied, and it is thus not uncommon for an idealized object to be devalued. Devaluation is often found with a sense of ingratitude. Klein (1975, pp. 217-218) provides an example:

A patient, who during an analytic session had arrived at a satisfactory solution to an external problem, started the next session by saying that he felt annoyed with me: I had roused great anxiety on the previous day in making him face this particular problem. It also appeared that he felt accused and devalued by me because, until the problem was analyzed, the solution had not occurred to him.

A defense Klein identified as being found especially in persons who carried a depressive trait is devaluation of the self $(1975, \mathrm{p} .218)$. When a person is unable to develop her gifts or use her gifts successfully, she protects herself from both her own aggressiveness and the envy of others by devaluing herself. At the same time, she can engage in self-punishment. 
"Depriving oneself of success has, of course, many determinants, and this applies to all the attitudes I am referring to," writes Klein (1975, p. 218).

Klein identifies three more defenses against envy (1975, pp. 218-220): internalizing the breast greedily, preventing the infant from loving the love object and claiming omnipotent control over the object; stirring up the envy of others through success or possessions while remaining suspicious of others; and stifling the feelings of love and corresponding intensifying of hate. Controlling the love object renders the object a destroyed persecutor, whereas stirring up the envy of others leaves one with guilt feelings and the need to repair. And, by stifling love and allowing hate to intensify, often in the form of indifference or withdrawal or even acting out, one also protects against guilt feelings, which are more painful to bear. When the envy is powerful, Klein felt that the defenses just mentioned are not very effective against the destructive, persecutory, and depressive anxieties envy unleashes (1975, p. 219). Rather, the defenses actually fuel the very envy the person wants to get away from.

Klein's Envy and Gratitude provides us with an understanding of more than the role of envy in our personal lives. The book addresses many related attitudes important for contemporary living, such as envy and ambition (1975, p. 199), envy and frigidity (1975, p. 200), envy and homosexuality or feminine attributes (1975, p. 201), envy and creativity (1975, p. 202), and envy and the compulsive need for reparation (1975, p. 214). I will leave exploration of these themes to the future.

\section{Samuel 18 revisited}

The Scripture passage addressed at the beginning of this essay-1 Samuel 18 - can be read through the lens of Klein and her understanding of envy as a consequence of the first relationship that was disturbed. By the time this narrative occurs, Saul had been pulled into the life of Israel's leader and prophet, Samuel. Despite God's warning that a king would take and use both persons and what the land offered, Israel reiterated their need for a king. God granted Israel their request.

Saul's childhood remains a mystery, though we can make a few educated assumptions about the young Saul. We know he was a son of Kish, a Benjamite with some means (1 Sam. 9:1). Saul, the narrator tells us, was handsome and a head taller than his peers. I imagine Saul being affirmed for his size and people envisioning a great future for the young man. There might even have been some idealization around Saul. We meet Saul when he was nearing 30 years of age, searching for his father's lost donkeys. His accompanying servant led him to Samuel. Saul resisted this idea, saying, "If we go, what can we give the man? The food in our sacks is gone. We have no gift to take to the man of God. What do we have?" (1 Sam. 9:7). One of the very first images we have is of a man with a keen sense of gratitude and protocol. He felt he had nothing to offer. Like any good servant would, Saul's servant came to his rescue by offering some silver. Saul struggled with guilt feelings, the result of a first relation that had been compromised.

Klein identified the depressive position as having fear of the destruction of others. Saul never reached the depressive position where the opposing forces of loving and hating were integrated into his person. Rather, he would regress to the paranoid-schizoid position as he feared David. In the interim, Samuel received word from God that a Benjamite was making his way to him and that he would be anointed king. Reassuring Saul that the donkeys had been found - an act of reparation in itself-Samuel invited Saul to a meal. Shortly thereafter, Samuel anointed Saul. Samuel also indicated a number of signs for Saul, and when those happened, God "changed" Saul's heart (1 Sam. 10:9). Samuel became Saul's idealized object but could not internalize him as a love object. 
Despite his changed heart but still feeling he had nothing to offer, Saul hid when Samuel and the other tribes of Israel were looking for him (1 Sam. 10:20), but being taller than all the others, he was easily spotted. Samuel proceeded and told the people that God had chosen Saul to be their king. Saul's newfound status, however, as explained to Israel by Samuel, immediately awakened envy in others (1 Sam. 10:26-27): "Then Samuel dismissed the people to go to their own homes. ... But some scoundrels said, "How can this fellow save us?" They despised him and brought him no gifts. But Saul kept silent.

Stirring up the envy of others, Klein reminded us, is a defense against envy: "A frequent method of defense is to stir up envy in others by one's own success, possessions, and good fortune, thereby reversing the situation in which envy is experienced" (Klein 1975, p. 218). Klein warns that this method is ineffective since it awakens paranoid, persecutory anxieties, which became all the more prevalent in Saul. Fearing destruction by others, Saul "kept a close eye on David," the narrator informs us (1 Sam. 18:9). Saul entered the paranoid-schizoid position.

Saul was 30 years old when he became king, and he ruled over Israel for 42 years (1 Sam. 13:1). He fathered four sons and two daughters and had great successes against his enemies (1 Sam. 14:47). Saul was blessed in many ways; the good breast, one can argue, provided. Despite these successes in bed and on the battlefield, Saul had trouble controlling his own impatience. Samuel told Saul to wait before entering battle with the Philistines, but after 7 days without Samuel showing up, the Israelites became restless. Against the orders of God, Saul attacked (1 Sam. 13). Saul's impatience tells something of his inner world; he lacked the hope and trust that the good breast would come, that the love object-Samuel and the promises of God Samuel held-would provide. Instead, Saul took matters greedily into his own hands. "Greed is an impetuous and insatiable craving, exceeding what the subject needs and what the object is able and willing to give," Klein writes $(1975$, p. 181). Greed, Klein also stated, can be a defense against envy. The good object that becomes the persecutor when we greedily internalize the breast is seen in God coming to Saul and punishing him for his impatience.

The cost of Saul's greedy and independent impatience was his kingship. The fact that he once was "a man after [God's] own heart" (1 Sam. 13:14) is now forgotten. The narrator relates that Saul also had trouble controlling his men, who, with his son Jonathan, disobeyed Saul's (and God's) direct orders (1 Sam. 14). A chapter later (1 Sam. 15:18-19), Samuel rebuked Saul for his impatience and poor leadership:

Samuel said, "Although you were once small in your own eyes, did you not become the head of the tribes of Israel? The Lord anointed you king over Israel. And he sent you on a mission, saying, 'Go and completely destroy those wicked people, the Amalekites; wage war against them until you have wiped them out.' Why did you not obey the Lord? Why did you pounce on the plunder and do evil in the eyes of the Lord?"

The rebuke offers us another view of the internal world of Saul. Despite his physique and good looks, Saul carried a deep sense of insecurity; Samuel informs us that Saul felt small in his own eyes. Devaluation of the self, Klein showed, is a defense against deep-seated envy (Klein 1975, p. 218). This devaluation not only reflects on the poor first relationship that Saul experienced, but it also awakened envy and greedy impatience.

Saul, recognizing his sin of impatience, asked for forgiveness through idealizing God. God rejects Saul's penitence (vv. 24-26):

Then Saul said to Samuel, "I have sinned. I violated the Lord's command and your instructions. I was afraid of the men and so I gave in to them. Now I beg you, forgive 
my sin and come back with me, so that I may worship the Lord." But Samuel said to him, "I will not go back with you. You have rejected the word of the Lord, and the Lord has rejected you as king over Israel!"

This rejection, which Saul knew as a memory of feeling from his first relationship, followed by the fact that Samuel too rejected Saul, hurt Saul deeply. At the same time, his feelings of love and gratitude diminished and his envy and aggression, especially toward David, intensified. Like the breast that is bitten by the infant and in response refuses to offer itself again, Saul received a triple rejection: God rejected him as a beloved, Samuel never saw him again (though Samuel mourns this, according to 1 Samuel 16:1), and Saul, in memory, is rejected by his first object relation, the breast. The Lord regretted making Saul king over Israel (1 Sam. 15:35).

The next chapter tells the story of how David is anointed. Though Saul was still officially king of Israel, the Lord's spirit had left him (1 Sam. 16:14). An "evil spirit" was sent from God to torment Saul, the "evil spirit" explanation the only one the narrator offered. Seeing Saul's agony, his servants recommended that David play the lyre for him to bring relief (vv. 15-16). Like a good breast, David's music had a positive effect on Saul, though the effect did not last. In chapter 17, David slayed Goliath and then Saul felt envy in the face of David's successes, joy, and happiness.

Saul, once a man loved and blessed by God, knew happiness. Happiness was more than a memory; it was a lived experience. That happiness, however, decreased and became envy as he saw David riding a wave of popularity and happiness, happiness that spilled over into the lives of ordinary townsfolk. The way Saul is portrayed in Scripture gives us a sense that he came compromised to his anointing as king. From having a low view of himself to being impatient and idealizing God, the poor first relation Saul had with the breast caught up with him.

Attempts by Saul to overcome his envy of David, such as offering David his daughter Michal in marriage or sending David into battle in an attempt to destroy him-representing the depressive and the paranoid-schizoid positions respectively-failed and could not bring happiness back to Saul. David became the bad object to be feared and Saul remained envious of him. Envy thus became the thread that tied Saul and David together. David, once king, envied Uriah, one of his officers and husband to Bathsheba, and the narrative of envy, now fused with jealousy, continued.

\section{Conclusion}

Klein (1975) taught us that deeper than family relationships, financial situations, and health, the first relationship, the one we had with the breast, is foundational to happiness. When that relationship is compromised, envy can set in. She also taught us that emotions tend to go in pairs: envy and gratitude, sadness and melancholia, destruction and reparation. . . . In this article, I argued that envy and happiness are intimate partners and that one cannot find one without the other. We all carry the memory of happiness, a memory established in the first relation we had with the breast, our primary object. We also carry memories of the breast refusing to feed or of a good feeding that became spoiled. When we observe the happiness of someone else, the pre-verbal memory of happiness is disturbed in us. We can either draw on our capacity to love and be happy, and rejoice with a person who is happy, or we can fall into the "evil spirit" of envy.

In a world where the rich are getting richer and the poor are getting poorer, where greed, hatred, aggression, guilt, and attempts at reparation are common themes, Klein can offer us not only a theory to understand individuals, but society. Klein can help us to make 
reparation of billions of lives shattered by greed and aggression and to love more deeply; she can help us to remember and memorialize the suffering of those who cannot be made whole again; her theory can help us to reform reason to make it less patriarchal and tied to power; and, Klein can also help us reconcile with what is natural (Alford 1989, p. 9). In this world, envy is a stirring giant, and one can expect an increase in envy unless good first relationships, strong enough to overcome the envy as described by Klein, are established. When happiness fills our lives, relationships, and the world with a sense of goodness, envy is its intimate enemy, searching for ways to spoil the happiness.

"Repeated happy experiences of being fed and loved are instrumental in establishing securely the good object," Klein reminded us (1975, p. 233). Happiness enriches the personality, as 100 Years of Happiness shows, but that enrichment receives new meaning if the person who is happy or the person witnessing happiness experienced reparation of their compromised first object relationship. Klein helps us see that all feelings, including happiness, reside in our memories. We can follow her and speak of the "memories in feeling" (1975, p. 234). These memories are a blessing and a burden as the call to maintain good relationships, especially with our first relationship, remains.

Acknowledgments I am grateful for Editor Lewis Rambo who saw the wisdom to address 100 Years of Happiness in a special book forum edition of Pastoral Psychology. And I am grateful for scholars like Donald Capps and Nathan Carlin, who show us the importance of happiness.

\section{References}

Alford, C. F. (1989). Melanie Klein and critical social theory: An account of politics, art, and reason based on her psychoanalytic theory. New Haven: Yale University Press.

Brueggemann, W. (1993). Texts under negotiation: The Bible and postmodern imagination. Minneapolis: Fortress Press.

Carlin, N., \& Capps, D. (2012). 100 years of happiness: Insights and findings from the experts. Santa Barbara: Praeger.

Greenberg, J. R., \& Mitchell, S. A. (1983). Object relations in psychoanalytic theory. Cambridge: Harvard University Press.

Hagedorn, A. C., \& Neyrey, J. H. (1998). "It was out of envy that they handed Jesus over" (Mark 15:10): the anatomy of envy and the Gospel of Mark. Journal for the Study of the New Testament, 15, 15-56.

Kim, A. Y. (2001). Cain and Abel in the light of envy: a study in the history of interpretation of envy in Genesis 4:1-16. Journal for the Study of the Pseudepigrapha, 12(1), 65-84.

Klein, M. (1975). Envy and gratitude, and other works: 1946-1963. London: Hogarth Press and the Institute of Psycho-Analysis.

Klein, M. (1984). Love, guilt, and reparation, and other works, 1921-1945. New York: Free Press.

Kristeva, J. (2001). Melanie Klein. New York: Columbia University Press.

Likierman, M. (2001). Melanie Klein: Her work in context. New York: Continuum.

Sanchez-Pardo, E. (2003). Cultures of the death drive: Melanie Klein and modernist melancholia. Durham: Duke University Press.

Sayers, J. (1991). Mothers of psychoanalysis: Helene Deutsch, Karen Horney, Anna Freud, Melanie Klein. New York: W. W. Norton.

Segal, J. (2004). Melanie Klein (2nd ed.). London: SAGE Publications.

The Holy Bible: New International Version (1984). Grand Rapids: Zondervan Publishing House. 